\title{
Screening of Sesbania accessions based on early biomass yield
}

\section{Sontosh C. Chanda, A. K. M. Azad-ud-Doula Prodhan and A. K. M. Golam Sarwar}

Laboratory of Plant Systematics, Department of Crop Botany, Bangladesh Agricultural University, Mymensingh-2202, Bangladesh

\section{ARTICLE INFO}

Article history:

Received: 27 September 2017

Accepted: 15 November 2017

Keywords:

Biomass, Selection, Sesbania,

Green manure

Correspondence:

A.K.M. Golam Sarwar

(drsarwar@bau.edu.bd)

\begin{abstract}
Soft, succulent and readily decomposable Sesbania biomass is one of the best sources of organic matter and nitrogen for improvement of poor, nutrient deficit soils. To select high biomass yielding Sesbania accession(s), an experiment was conducted at Field Laboratory of the Department of Crop Botany, Bangladesh Agricultural University, Mymensingh, following a randomized complete block design with three replications. Seeds of 105 accessions from 3 Sesbania species-S. sesban, S. bispinosa and S. cannabina, were sown in the field @ $60 \mathrm{~kg} / \mathrm{ha}$ on 23 April 2016. The unit plot size was $3 \times 2 \mathrm{~m}^{2}$ with a spacing of $50 \mathrm{~cm}$ (row-row) $\times 15 \mathrm{~cm}$ (plant-plant). Data on different yield descriptors were recorded at every 10 day intervals up to 60 days after sowing (DAS). Sesbania sesban produced higher biomass yield at the early growth stages (up to $20 \mathrm{DAS}$ ), however, S. bispinosa produced higher biomass at the later stages followed by $S$. cannabina and S. sesban. Therefore, S. sesban can be grown in a very short rotation [Boro rice-(dhaincha)-Jute-T. Aman rice-Mustard and/or Boro rice-(dhaincha)-T. Aus rice-T. Aman riceMustard]; and S. bispinosa for a longer period [Boro rice-(dhaincha)-T. Aman rice-Mustard] to maximize organic matter addition to the soil. Ten accessions of S. bispinosa performed better and produced biomass above $30 \mathrm{~g} / \mathrm{plant}(c .80 \mathrm{t} / \mathrm{ha}$ ) within 60 DAS. These accessions could be selected for further study for their decomposability, organic matter accumulation, $\mathrm{N}_{2}$-fixing ability and may be processed to release as recommended cultivar(s).
\end{abstract}

\section{Introduction}

In Bangladesh, soil organic matter content is below $1 \%$ in more than $60 \%$ of cultivable lands compared to an ideal minimum value of $3 \%$ and decreasing day by day (Anon., 2012). As a result, land faces a threat to crop production and cultivable lands lose its productivity (Alam and Salahin, 2013). Moreover, soil fertility has caused exhaustion in Bangladesh due to intensive land use and mostly monoculture of rice crop without green manuring. In this situation cultivable lands become worse and crop production goes downward (Anon., 2012). This poor soil may become fertile after 10-12 years continuous cultivation and incorporation of Sesbania green manure (Carroll and Somerville, 2009). Sesbania sp. is a quick growing green manure crop which has extreme tolerance to both drought and waterlogged conditions (Heering and Gutteridge, 1992). It is soft, succulent and readily decomposable in soil (Dhaka et al., 2014), but become woody at the later stage of growth i.e. 60 or more days after sowing (Pandey et al., 2013). It could also be grown as ground cover, providing wood, firewood and other uses in traditional agroforesty systems (Ndoye et al., 1990) and other utilizations such as fuel, bio-energy and fiber sources, live support fencing as well (Heering and Gutteridge, 1992; Veasey et al., 1999; Sarkar et al., 2017). Three Sesbania species viz. S. sesban (L.) Merr., S. bispinosa (Jacq.) W. Wight [former S. aculeata (Wild.) Poir.] and S. cannabina (Retz.) Poir., are commonly used as green manure crops in Bangladesh (Ahmed et al., 2009). Sesbania bispinosa sometimes produces $c .80$ t/ha biomass at 60 days during monsoon season (Chanda et al., 2017).

The unavailability of land is one of the main constraints for green manure crop cultivation in Bangladesh. A total of 294 cropping patterns exist at the farm level in different agro-ecological zones of Bangladesh (Anon., 2012). The major cropping patterns mostly consist of rice based cereal crops; more than $60 \%$ of the total cropped area is covered by (Boro) Rice-Fallow-Rice (T. Aman) cropping pattern (Haque, 1998; Anon., 2012). Another existing popular cropping pattern is Winter Vegetables/Mustard-Boro rice-T. Aman rice in Bangladesh. In these cropping patterns, land remains fallow for more or less 80 days after Boro rice harvest (Haque et al., 2001; Khan et al., 2004). Four crops based cropping patterns (Boro rice-T. Aus rice-T. Aman rice-Mustard or Boro rice-Jute-T. Aman rice-Mustard) require 345-351 days excluding seedling age of rice crop and the land area remains fallow only for 14-20 days in a year (Mondol et al., 2015; Rahman et al., 2015). During the turnover period between Boro rice harvest and succeeding crop cultivation, the land remains fallow for 14-80 days. The short fallow period could be utilized by cultivating high biomass producing Sesbania accessions at the early growth stages; and high biomass producing Sesbania accessions at the later growth stages may be cultivated during long fallow period in order to improve soil health and fertility. Hitherto, the National Seed Board of Bangladesh has not so far recommended any cultivar of dhaincha (Sesbania 
spp.) for green manure production (Sarwar et al., 2015). The present study was, therefore, undertaken to screen out the Sesbania accessions based on biomass yield at different days after sowing to fit in the 20-60 days fallow period after Boro rice harvest.

\section{Materials and Methods}

An experiment was conducted at Field Laboratory of the Department of Crop Botany, Bangladesh Agricultural University, Mymensingh, for the screening of Sesbania accessions on the basis of their biomass yield during 1060 days after sowing (DAS). A randomized complete block design was followed with three replications. The unit plot size was $3 \times 2 \mathrm{~m}^{2}$ and seeds were sown @ 60 $\mathrm{kg} / \mathrm{ha}$ with the spacing at $50 \mathrm{~cm}$ (row-row) $\times 15 \mathrm{~cm}$ (plant-plant). Seeds of 105 Sesbania accessions (90 accessions belong to $S$. bispinosa, 9 accessions to $S$. cannabina and 6 accessions to $S$. sesban) were collected from 19 districts of Bangladesh (detail collection information available upon request). Seeds were sown in the experimental field on 23 April, 2016.

The quantitative data viz. plant height, base diameter, root length, fresh and dry weight of root \& shoot, and total biomass weight, were recorded at 10 days interval up to 60 DAS. The data were taken as the mean value of 10 representative samples per accession. Plant height was measured using a meter scale and base diameter was measured by a digital slight caliper with a precision of $0.1 \mathrm{~mm}$ to $150 \mathrm{~mm}$ (Ribeiro et al., 2015). Sample fresh and dry weights were taken by a digital balance and fresh samples were dried at $72^{\circ} \pm 2^{\circ} \mathrm{C}$ for $72 \mathrm{hrs}$. Data were analyzed with Excel application to determine the arithmetic mean, standard deviation, coefficient of variance, and range among the accessions (de Melo et al., 2016).

\section{Results and Discussion}

Biomass yield and other yield contributing parameters of Sesbania species varied and increased significantly up to 60 days after sowing (DAS). Plant height of Sesbania species-S. bispinosa, S. cannabina and $S$. sesban, varied among the species and the longest plant was observed in $S$. sesban $(11.9 \mathrm{~cm})$ followed by $S$. bispinosa $(10.1 \mathrm{~cm})$ and $S$. cannabina $(9.53 \mathrm{~cm})$ at 10 DAS (Table 1). Shreelalitha et al. (2015) collected two wild legumes, $S$. bispinosa and $S$. speciosa from mangroves of south India and found that the shoot length of $S$. bispinosa was $3.8 \mathrm{~cm}$ and of $S$. speciosa was $7.1 \mathrm{~cm}$ at 10 DAS. The plant height may differ due to their genetic make-up and environmental effects as well. At 20 DAS, the highest plant height was also observed in $S$. sesban followed by $S$. cannabina and S. bispinosa. The result revealed that $S$. sesban performed better at the early growth stages than $S$. bispinosa and $S$. cannabina. On the contrary, $S$. bispinosa produced the longest plant and the shortest one in S. sesban from 30 to 60 DAS (Table 1). The plant height may differ due to the genetic make-up of the Sesbania spp. (Sarwar et al., 2015). Veasey et al. (1999) found similar result in Sesbania species and reported that the plant height (mean value of 17 Sesbania species) were 8.95, 30.78, 60.55 and $86.07 \mathrm{~cm}$ at $17,32,47$ and 62 DAS, respectively.

The longest root was found in $S$. cannabina $(4.30 \mathrm{~cm})$ and shortest one in $S$. sesban $(2.91 \mathrm{~cm})$ at 10 DAS (Table 2). Shreelalitha et al. (2015) observed in two wild legume Sesbania spp. from mangroves of south India and reported that the root length of S. bispinosa was $1.8 \mathrm{~cm}$ and $S$. speciosa was $2.5 \mathrm{~cm}$ at 10 DAS. At 20 DAS, the highest root length was produced in $S$. sesban followed by $S$. bispinosa and $S$. cannabina. However, the highest root length was found in $S$. bispinosa followed by $S$. sesban and $S$. cannabina from 30 to 60 DAS (Table 2). The root length among the species may differ due to the genetic make-up (Sarwar et al., 2015).

The highest base diameter was obtained from $S$. sesban and lowest both in S. bispinosa and S. cannabina at 10 and 20 DAS (Table 3). However, the highest base diameter was found in $S$. bispinosa followed by $S$. sesban and $S$. cannabina between 30 and 40 DAS. Nevertheless, highest base diameter was observed in S. bispinosa $(1.01 \mathrm{~cm})$ followed by $S$. cannabina $(0.90 \mathrm{~cm})$ and $S$. sesban $(0.85 \mathrm{~cm})$ at 50 and 60 DAS (Table 3). Rahman et al. (2016) reported that the highest base diameter was $0.92 \mathrm{~cm}$ and lowest was $0.79 \mathrm{~cm}$ when $S$. bispinosa crop harvested at 60 DAS. The base diameter varied due to the genetic make-up and environmental effects (Sarwar et al., 2015; Rahman et al., 2016).

Table 1. Plant height (cm) of Sesbania spp. at different days after sowing (Mean \pm Sd)

\begin{tabular}{lllllll}
\hline Species & 10 DAS & 20 DAS & 30 DAS & 40 DAS & 50 DAS & 60 DAS \\
\hline S. bispinosa & $10.1 \pm 0.70$ & $12.2 \pm 2.07$ & $38.3 \pm 8.14$ & $66.7 \pm 10.9$ & $91.3 \pm 18.8$ & $140.1 \pm 27.5$ \\
S. cannabina & $9.53 \pm 1.06$ & $12.7 \pm 2.60$ & $32.8 \pm 4.88$ & $60.1 \pm 7.99$ & $88.7 \pm 25.8$ & $127.0 \pm 30.8$ \\
S. sesban & $11.9 \pm 1.37$ & $13.8 \pm 0.63$ & $30.5 \pm 12.2$ & $44.2 \pm 11.7$ & $75.0 \pm 24.7$ & $97.5 \pm 7.74$ \\
\hline
\end{tabular}


Table 2. Root length (cm) of Sesbania spp. at different days after sowing (Mean \pm Sd)

\begin{tabular}{lllllll}
\hline Species & 10 DAS & 20 DAS & 30 DAS & 40 DAS & 50 DAS & 60 DAS \\
\hline S. bispinosa & $4.03 \pm 0.85$ & $6.68 \pm 1.37$ & $11.8 \pm 1.79$ & $15.3 \pm 1.51$ & $18.1 \pm 2.81$ & $23.2 \pm 2.77$ \\
S. cannabina & $4.30 \pm 1.19$ & $6.60 \pm 1.70$ & $10.0 \pm 2.23$ & $14.6 \pm 1.19$ & $18.3 \pm 2.35$ & $23.2 \pm 2.72$ \\
S. sesban & $2.91 \pm 0.51$ & $7.76 \pm 1.30$ & $11.0 \pm 1.74$ & $14.1 \pm 1.22$ & $17.6 \pm 0.96$ & $20.2 \pm 2.96$ \\
\hline
\end{tabular}

Table 3. Base diameter $(\mathrm{cm})$ of Sesbania spp. at different days after sowing (Mean \pm Sd)

\begin{tabular}{lllllll}
\hline Species & 10 DAS & 20 DAS & 30 DAS & 40 DAS & 50 DAS & 60 DAS \\
\hline S. bispinosa & $0.05 \pm 0.01$ & $0.10 \pm 0.02$ & $0.32 \pm 0.07$ & $0.48 \pm 0.08$ & $0.70 \pm 0.15$ & $1.01 \pm 0.15$ \\
S. cannabina & $0.05 \pm 0.01$ & $0.09 \pm 0.02$ & $0.26 \pm 0.06$ & $0.41 \pm 0.06$ & $0.61 \pm 0.14$ & $0.90 \pm 0.17$ \\
S. sesban & $0.07 \pm 0.01$ & $0.12 \pm 0.02$ & $0.29 \pm 0.07$ & $0.42 \pm 0.09$ & $0.57 \pm 0.87$ & $0.85 \pm 0.16$ \\
\hline
\end{tabular}

Other biomass yield contributing characters i.e., fresh and dry weight of shoot \& root, are presented in Fig. 1. Sesbania bispinosa produced the highest shoot fresh weight at 60 DAS followed by $S$. cannabina and $S$. sesban (Fig. 1A). The root fresh weight was double at every 10 days interval from 30 to 60 DAS in all the species (Fig. 1B). Shoot dry weight of $S$. bispinosa was doubled from 30 to 40 DAS, tripled from 40 to 60 DAS. The growth trend of shoot biomass was different in $S$. cannabina and $S$. sesban. In both $S$. cannabina and $S$. sesban, shoot dry weight was increased 3 times from 30 to 50 DAS, and two \& a half times between 50 to 60 DAS (Fig. 1C). The root dry weight of S. bispinosa and $S$. cannabina became two and a half times higher, but doubled in S. sesban, at every 10 days interval from 30 to 60 DAS (Fig. 1D). These variations in root growth may be occurred due to genetic make-up of Sesbania spp. (Sarwar et al., 2015). Manh et al. (2003) reported that the initial growth of Moringa oleifera and some leguminous crops is slow and gradually increases within course of time.

The highest total biomass yield was observed in $S$. sesban and the lowest was in both $S$. bispinosa and $S$. cannabina at 10 DAS (Table 4). The result revealed that $S$. sesban produced higher biomass at the early growth stages (up to 20 DAS) comparatively that of other two species. After 20 DAS, it produced lower biomass compared to $S$. bispinosa and S. cannabina (Table 4). We can raise-up high biomass yielding $S$. sesban accessions for green manure in four crops based cropping patterns e.g., Boro rice-(Dhaincha)-Jute-T. Aman rice-Mustard, Boro rice-(Dhaincha)-T. Aus rice-
T. Aman rice-Mustard, etc. Among the $S$. sesban accessions, number 81,82 and 85 produced higher amount of biomass than three other accessions (\#66, 70 and 79) (up to 20 DAS; data not shown here). On the other hand, S. bispinosa produced the highest biomass yield followed by $S$. cannabina and $S$. sesban at 30 to 60 DAS. After Boro rice harvest land remains fallow more or less 80 days in (Boro) Rice-Rice (T. Aman) cropping pattern (Khan et al., 2004). The higher biomass yielding $S$. bispinosa accessions may be grown after Boro rice harvest, and the long fallow period in (Boro) Rice(Dhaincha)-Rice (T. Aman) or (Boro) Rice-(Dhaincha)Rice (T. Aman)-Winter vegetables/Mustard cropping patterns could be utilized for green manure production. Accession number 5, 30, 31, 44, 71, 77, 78, 86, 90, and 109 of $S$. bispinosa produced higher biomass (above 30 g/plant) at 60 DAS (Table 5). Among these accessions, number 77 produced highest biomass (33.51 g/plant) followed by number 44 (32.85 g/plant) and number 90 $(32.67 \mathrm{~g} / \mathrm{plant})$. At $60 \mathrm{DAS}$, the total biomass yield ratio among these three Sesbania species-S. bispinosa, $S$. cannabina and $S$. sesban was 3:2:1, respectively (Table 4). Ten high biomass yielding Sesbania accessions, all are belong to the species S. bispinosa, are selected for further studies to be released as recommended cultivar(s) (Table 5). Rajbhandari (1984) observed that the crop S. bispinosa harvested at 24, 36 and 48 DAS resulted in fresh biomass yield of 2.2, 11.5 and $26.3 \mathrm{t} / \mathrm{ha}$, respectively. Fownes and Anderson (1991) reported that above ground biomass (shoot+leaf) of $S$. sesban were $2.1,9.5,18.0,21.2$ and $25.3 \mathrm{~g} / \mathrm{plant}$ at $5,9,11,13$ and 15 week, respectively.

Table 4. Biomass (g/plant) of Sesbania spp. at different days after sowing (Mean \pm Sd)

\begin{tabular}{lllllll}
\hline Species & 10 DAS & 20 DAS & 30 DAS & 40 DAS & 50 DAS & 60 DAS \\
\hline S. bispinosa & $0.008 \pm 0.001$ & $0.112 \pm 0.045$ & $1.23 \pm 0.578$ & $2.56 \pm 0.927$ & $7.27 \pm 2.97$ & $18.63 \pm 6.28$ \\
S. cannabina & $0.008 \pm 0.001$ & $0.093 \pm 0.036$ & $0.786 \pm 0.406$ & $2.03 \pm 0.812$ & $5.79 \pm 2.93$ & $14.05 \pm 6.83$ \\
S. sesban & $0.014 \pm 0.04$ & $0.118 \pm 0.029$ & $0.708 \pm 0.493$ & $1.34 \pm 0.635$ & $2.75 \pm 0.90$ & $6.48 \pm 2.23$ \\
\hline
\end{tabular}



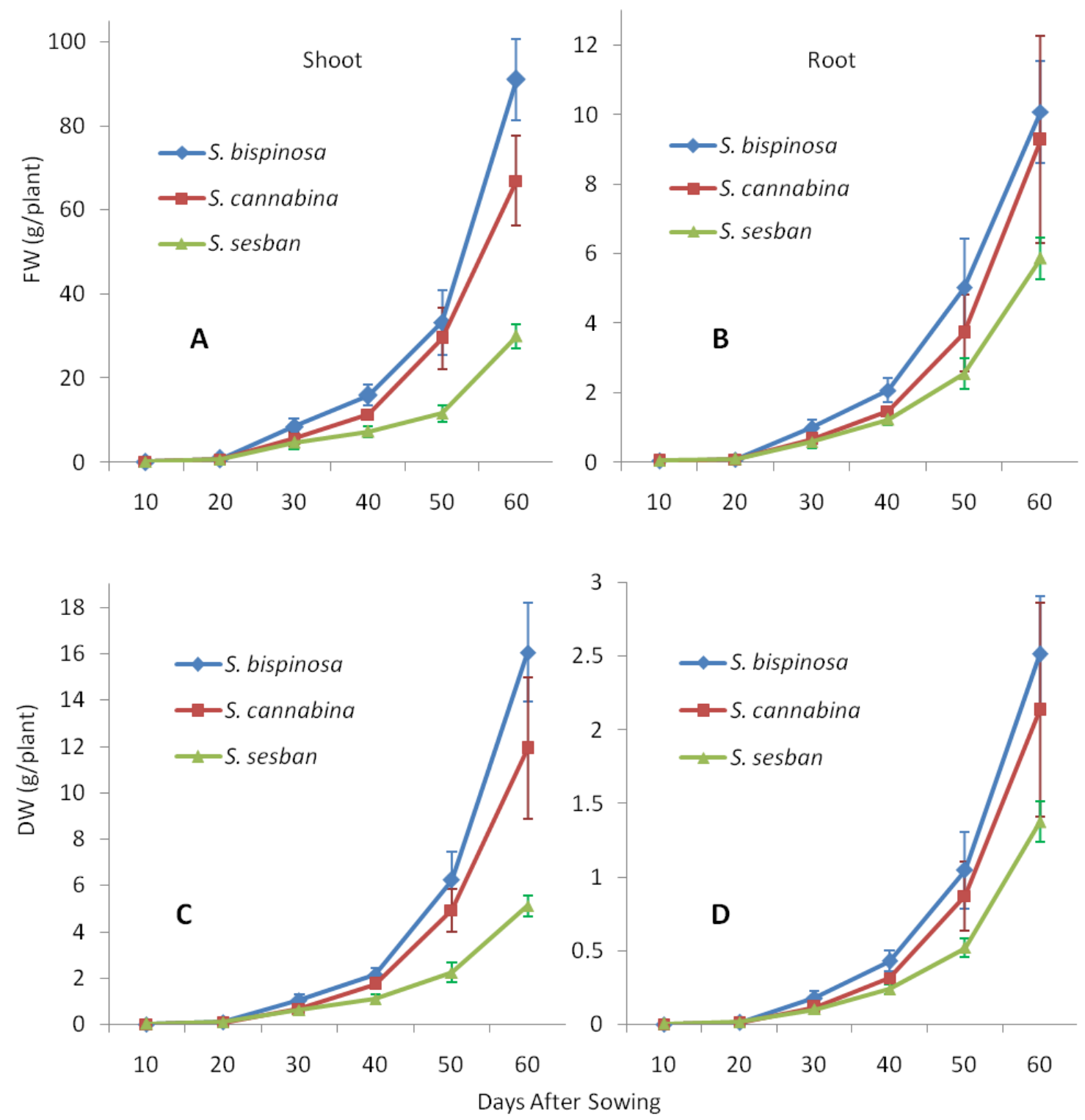

Fig. 1. (A) Shoot fresh weight (g/plant), (B) root fresh weight (g/plant), (C) shoot dry weight (g/plant), (D) root dry weight (g/plant) of Sesbania species at different days after sowing. Vertical bars showing the \pm SEM $(n=3)$.

Table 5. Biomass yield contributing descriptors of selected $S$. bispinosa accessions at 60 days after sowing

\begin{tabular}{|c|c|c|c|c|c|c|c|c|}
\hline \multirow{2}{*}{$\begin{array}{c}\text { Accession } \\
\text { No. }\end{array}$} & \multirow{2}{*}{$\begin{array}{l}\text { Plant height } \\
\quad(\mathrm{cm})\end{array}$} & \multirow{2}{*}{$\begin{array}{l}\text { Root length } \\
\quad(\mathrm{cm})\end{array}$} & \multirow{2}{*}{$\begin{array}{l}\text { Base diameter } \\
(\mathrm{cm})\end{array}$} & \multicolumn{2}{|c|}{$\begin{array}{l}\text { Shoot weight } \\
\text { (g/plant) }\end{array}$} & \multicolumn{2}{|c|}{$\begin{array}{c}\text { Root weight } \\
\text { (g/plant) }\end{array}$} & \multirow{2}{*}{$\begin{array}{c}\text { Total } \\
\text { biomass } \\
\text { (g/plant) }\end{array}$} \\
\hline & & & & Fresh & Dry & Fresh & Dry & \\
\hline 05 & 165.00 & 24.30 & 1.10 & 117.60 & 26.74 & 12.44 & 3.37 & 30.11 \\
\hline 30 & 151.90 & 25.60 & 1.15 & 111.26 & 26.21 & 13.82 & 4.74 & 30.95 \\
\hline 31 & 168.30 & 24.45 & 1.27 & 141.22 & 24.55 & 20.24 & 5.84 & 30.39 \\
\hline 44 & 186.10 & 25.20 & 1.51 & 195.00 & 29.50 & 13.26 & 3.35 & 32.85 \\
\hline 71 & 184.70 & 24.42 & 1.24 & 150.00 & 27.10 & 14.27 & 4.09 & 31.19 \\
\hline 77 & 192.60 & 25.10 & 1.28 & 180.00 & 29.50 & 14.73 & 4.01 & 33.51 \\
\hline 78 & 178.20 & 28.63 & 1.22 & 165.00 & 27.13 & 13.82 & 3.77 & 30.90 \\
\hline 86 & 162.00 & 26.12 & 1.14 & 114.75 & 27.97 & 14.88 & 3.61 & 31.58 \\
\hline 90 & 185.00 & 24.40 & 1.19 & 161.61 & 28.16 & 16.44 & 4.51 & 32.67 \\
\hline 109 & 180.00 & 23.20 & 1.15 & 185.00 & 26.85 & 14.33 & 4.30 & 31.15 \\
\hline CV $(\%)$ & 7.38 & 5.83 & 9.50 & 20.00 & 5.47 & 14.69 & 18.03 & 3.55 \\
\hline
\end{tabular}




\section{Conclusion}

From the above discussion, it may conclude that higher biomass producing, at the earlier growing period, $S$. sesban accessions could be easily fitted and used as green manure crop in shorter fallow period (up to 20 DAS) of Boro rice-(dhaincha)-Jute-T. Aman riceMustard and/or Boro rice-(dhaincha)-T. Aus rice-T. Aman rice-Mustard or similar cropping patterns. Moreover, higher biomass producer, at the later growing period (30 to 60 DAS), S. bispinosa accessions can be fitted well when land is available for longer period in Boro rice-(dhaincha)-T. Aman rice-Mustard/Winter vegetables, or Boro rice-(dhaincha)-T. Aman rice, or similar cropping patterns. Based on biomass yield, three S. Sesban accessions (\#81, 82 and 85; produced above $0.12 \mathrm{~g} /$ plant of biomass at 20 DAS) and ten accessions of $S$. bispinosa (\#5, 30, 31, 44, 71, 77, 78, 86, 90, and 109; produced above $30 \mathrm{~g} /$ plant of biomass at $60 \mathrm{DAS}$ ) could be screened out. These higher yielding accessions would be processed further to release as recommended cultivar(s).

\section{Acknowledgements}

We acknowledge the financial support of the Ministry of Science and Technology, Government of the People's Republic of Bangladesh.

\section{References}

Ahmed, Z.U.,Hassan, M.A., Begum, Z.N.T., Khondker, M., Kabir, S.M.H., Ahmad, M. Ahmed, A.T.A. (eds). 2009. Encyclopedia of Flora and Fauna of Bangladesh, Vol. 8. Angiosperms: Dicotyledons (Fabaceae-Lythraceae). Asiatic Soc. Bangladesh, Dhaka. pp. 1-474.

Alam, M.K. and Salahin, N. 2013. Changes in soil physical properties and crop productivity as influenced by different tillage depths and cropping patterns. Bangladesh J. Agril. Res., 38: 289299.

Anonymous. 2012. Fertilizer Recommendation Guide. $6^{\text {th }}$ ed. Hassan, A.A., Jahiruddin, M., Noor, S., Sarker, M.J.U., Shah, A.L., Khan, M.M.K., Bokhtiar, S.M., Quddus, M.A., Hasan, M.N., Razia, S. and Satter, M.A. (eds), Bangladesh Agril. Res. Coun., Dhaka. p. 275.

Carroll, A. and Somerville, C. 2009. Cellulosic biofuels. Ann. Rev. Plant Biol., 60: 165-182.

Chanda, S.C., Prodhan, A.K.M.A. and Sarwar, A.K.M. Golam. 2017. Screening of dhaincha accessions based on biomass yield. Abs. AGROTECH-2017, Kalingpong, India. May 11-12, 2017. p: 1 .

de Melo, P.A.F.R., Silva, K.B., Alves, E.U., de Medeiros, R.L.S., dos Anjos, Neto, A.P., Pinto, K.M.S., de Sousa, Leite, W. and Matos, V.P. 2016. Morphological analysis of fruits, seeds and seedling germination Acacia farnesiana (L.) Willd. African J. Agril. Res., 11: 2913-2919.

Dhaka, A.K., Kumar, S., Pannu, R., Ramprakash, K., Singh, B., Singh, K. 2014. Yield performance and economics of pearl millet (Pennisetum glaucum) influenced in seed crop of dhaincha (Sesbania aculeata). Hariana J. Agron., 30: 129-137.

Fownes, J.H. and Anderson, D.G. 1991. Changes in nodule and root biomass of Sesbania sesban and Leucaena leucocephala following copping. Plant Soil, 138: 9-16.

Haque, M.F., Razzaque, M.A., Akhteruzzaman, A. (eds) 2001. A compendium: Packages of Technologies. A handbook for
Farming System Development. FSRD program. Bangladesh Agril. Res. Coun., Dhaka. p: 12.

Haque, M.S. 1998. Integrated nutrient management with inorganic and bio-fertilizers in legume based cropping patterns. Proceedings of the National Workshop on Integrated Nutrient Management for Crop Production and Soil Fertility. 24-25 March, 1998. BARC, Gazipur, pp: 99-109.

Heering, J.H. and Gutteridge, R.C. 1992. Sesbania sesban (L.) Merrill. In: 't Mannetje, L. and Jones, R.M.(eds.). Plant Resources of South East Asia, No. 4: Forages, pp. 198-201. Pudoc, Wageningen, The Netherlands.

Khan, A.H., Rashid, H., Khatun, A., Quddus, M.A. and Gomosta, A.R. 2004. Rice farming system: improved rice-based cropping system for different ecosystems. Paper presented at the National Farming Systems Technology Inventory Workshop held at CERDI, Gazipur, July 17-19, 2004.

Manh, L.H., Dung, N.X. and Xuan, V.T. 2003. Biomass production of Moringa oleifera and some legumes in the hilly area of Tinh Bien district, An Giang Province. In: Proc. Final Nat. Semin.-Works. Sustain. Livest. Prod. Local Feed Resour. Preston R and Ogle B (eds.). HUAF-SAREC, Hue City, March 25-28. Retrieved September 23, 2017, from http://www.mekarn.org/sarec03/manhcantho2.htm

Mondol, R.I., Begum, F., Aziz, A. and Sharif, S.H. 2015. Crop sequences for increasing intensity and productivity. SAARC J. Agri., 13: 135-147.

Ndoye, L., Tomekpe, K. and Dreyfus, B.1990. Sesbania and Rhizobium symbiosis: nodulation and nitrogen fixation. In: Macklin, B. and Evans, D.O. (eds) Perennial Sesbania Species in Agroforestry Systems. Nitrog. Fix. Tree Assoc. Waimanalo, pp: 31-38.

Pandey, V.P., Chaudhary, V.P. and Gangwar, B. 2013. Green manuring; Boon for Rice Farmers, Organic Agriculture. National Innovation on Climate Resilient Agriculture Project, Project Directorate for Farming System Research, U.P. India. pp: 1-5. Retrieve on; 02/06/2016.

Rahman, M.H., Ahmed, S., Samanta, S.C. and Ahsan, S.M. 2016. Effect of seed rate on biomass production of dhaincha (Sesbania aculeata). Asian-Aust. J. Biosci. Biotech., 1: 316322.

Rahman, M.M., Rahman, M.A., Ahmed, M., Uddin, M.M. and Choudhury, A.K. 2015. Improvement from Mustard-Boro-T. Aman cropping pattern to Mustard-Boro-Jute-T. Aman. Bangladesh J. Agril. Res., 40: 259-270.

Rajbhandari, N.K. 1984. The effect of age of two leguminous green manure crops on transplanted rice yield. M. Sc. (Ag.) Thesis, Univ. Philippines at Los Banos, Philippines.

Ribeiro, J.W.F., de Oliveira, A.K.M., Rodrigues, A.P.D.A.C. and Rondon, E.V. 2015. Germination and morphology of seed and seedlings of Parkia gigantocarpa Fabaceae: Mimosoidae. Floresta, 45: 303-614.

Sarkar, M., Sutradhar, S., Sarwar, A.K.M. Golam, Uddin, M.N., Chanda, S.C. and Jahan, M.S. 2017. Variation of chemical characteristics and pulp ability of dhaincha (Sesbania bispinosa) on location. J. Bioresour. Bioprod., 2: 24-29.

Sarwar, A.K.M. Golam, Islam, A. and Jahan, S. 2015. Characterization of Dhaincha accessions based on morphological descriptors and biomass production. $J$. Bangladesh Agril. Univ., 13: 55-60.

Shreelalitha, S.J., Sridhar, K.R. and Sukesh, S. 2015. Seed dormancy and germination in two wild genotypes of Sesbania of the southwest mangroves in India. J. Agril. Technol., 11: 895902.

Veasey, E.A., Schammass, E.A., Vencovsky, R., Martins, P.S. and Bandel, G. 1999. Morphological and agronomic characterization and estimates of genetic parameters of Sesbania Scop. (Leguminosae) accessions. Gene. Mole. Biol., 22: 81-93. 